\title{
PENGARUH PERPUTARAN KAS DAN PERPUTARAN PIUTANG TERHADAP PENGEMBALIAN LABA ATAS ASET PADA PERUSAHAAN SEKTOR FARMASI YANG TERDAFTAR DI BURSAEFEK INDONESIA (BEI) PERIODE 2014 - 2019
}

\author{
Indah Dwi Pratiwi ${ }^{1}$, Rustam Effendi ${ }^{2}$ \\ 1, Alumni jurusan Manajemen, Universitas Tridinanti, Sumatera Selatan \\ 2, Dosen jurusan Manajemen, Universitas Tridinanti, Sumatera Selatan \\ 1)Email : rustameffendi219@gmail.com
}

\section{INFORMASI ARTIKEL}

Submitted:

06/01/2021

Revised:

$25 / 05 / 2021$

Accepted:

$27 / 06 / 2021$

Online-Published:

$30 / 06 / 2021$

\begin{abstract}
ABSTRAK
Penelitian ini bertujuan untuk mengetahui: pengaruh perputaran kas dan perputaran piutang baik secara simultan maupun parsial terhadap return on assets/pengembalian laba atas aset pada perusahaan farmasi periode 20142019. Teknik pengambilan sampel yang digunakan adalah purposive sampling. Jumlah sampel adalah 6 perusahaan dari 10 perusahaan. Jenis penelitian ini adalah penelitian kuantitatif dan jenis data yang digunakan adalah data sekunder berupa laporan keuangan yang diperoleh melalui http://www.idx.co.id. Uji prasyarat analisis menggunakan uji normalitas, uji multikolinearitas, uji heteroskedastisitas, dan uji autokorelasi. Teknik analisis data yang digunakan adalah analisis regresi linier berganda.

Hasil statistik menunjukkan bahwa secara simultan Perputaran Kas dan Perputaran Piutang, baik secara simultan maupun parsial, Terhadap Return On Asset/Pengembalian Laba atas Aktiva. Hal ini terlihat dari uji F dengan nilai signifikansi 0,039 <0,05. Kemudian, hasil koefisien determinasi dengan nilai $R$ Square sebesar 0,178 atau sebesar 17,8\%. Nilai ini menunjukkan bahwa Perputaran Kas dan Perputaran Piutang berpengaruh terhadap Return on Assets/Return on Assets sebesar 17,8\%, sedangkan sisanya 82,8\% dipengaruhi oleh variabel lain yang tidak diteliti. Hasil statistik Perputaran Kas secara parsial berpengaruh terhadap Return On Assets/Pengembalian Laba terhadap Aktiva. Hal ini terlihat dari uji $t$ dengan nilai signifikansi 0,042<0,05. Hasil statistik Perputaran Piutang secara parsial berpengaruh terhadap Return on Asset/Pengembalian Laba atas Aktiva. Hal ini terlihat dari uji t dimana nilai signifikansinya 0,039 < 0,05.

Kata kunci: Perputaran Kas, Perputaran Piutang dan Return On Assets.
\end{abstract}

\begin{abstract}
ABSTRACK
This study aims to determine: the effect of cash turnover and accounts receivable turnover, either simultaneously or partially, on the return on assets/profit returns on assets in pharmaceutical companies for the period 2014-2019. The sampling technique used was purposive sampling. The number of samples is 6 companies from 10 companies. This type of research is quantitative research and the type of data used is secondary data in the form of financial reports obtained through http://www.idx.co.id. The prerequisite analysis test used the normality test, multicollinearity test, heteroscedasticity test, and autocorrelation test. The data analysis technique used is multiple linear regression analysis.

The statistical results show that simultaneously Cash Turnover and Accounts Receivable Turnover, either simultaneously or partially, Against Return On Assets / Returns of profit on Assets. This can be seen from the F test with a significant value of $0.039<0.05$. Then, the results of the coefficient of determination with an $R$ Square value of 0.178 or equal to $17.8 \%$. This value shows that Cash Turnover and Accounts Receivable Turnover affect the Return on Assets / Return on Assets by 17.8\%, while the remaining $82.8 \%$ is influenced by other variables not examined. The statistical results of cash turnover partially have an effect on Return On Assets / Returns of profit on Assets. This can be seen from the t test with a significant value of $0.042<0.05$. The statistical results of accounts receivable turnover partially affect the Return on Assets / Returns of profit on Assets. This can be seen from the t test where the significant value is $0.039<0.05$.

Keywords: Cash Turnover, Accounts Receivable Turnover and Return On Assets.
\end{abstract}




\section{A. PENDAHULUAN}

Setiap perusahaan mempunyai tujuan serta sasaran untuk mengukur keberhasilan perusahaannya masing- masing, dalam mengukur keberhasilan perusahaan diperlukan penilaiankinerja suatu perusahaan yang umumnya dilakukan melalui penilaian laporan keuangan perusahaan tersebut.

Laporan keuangan digunakan sebagai media komunikasi antara manajemen dengan para penggunanya.Informasi yang terkandung dalam laporan keuangan sangat bervariasi dan dapat digunakan untuk analisis rasio keuangan.

Evaluasi kinerja keuangan dapat dilihat menggunakan analisis rasio keuangan. Rasio - rasio yang digunakan untuk menilai kinerja keuangan perusahaan seperti rasio likuiditas, rasio leverage, rasio aktivitas dan rasio profitabilitas. Analisis rasio memungkinkan manajer keuangan dan pihak yang berkepentingan untuk menganalisis kondisi keuangan apakah menunjukkan kondisi sehat atau tidaknya perusahaan.

Analisis rasio juga menghubungkan unsur-unsur rencana dan perhitungan laba rugi sehingga dapat mengukur efektivitas dan efisiensi perusahaan. Laba perusahaan itu sendiri dapat diukur melalui rasio profitabilitas. Rasio Profitabilitas merupakan rasio yang bertujuan untuk mengetahui kemampuan perusahaan dalam menghasilkan laba selama periode tertentu dan juga memberikan gambaran tentang tingkat efektifitas manajemen dalam melaksanakan kegiatan operasionalnya. Efektifitas manajemen disini dilihat dari laba yang dihasilkan terhadap penjualan dan investasi perusahaan.

Rasio profitabilitas menggambarkan kemampuan perusahaan dalam pengelolaan modal akan efektifitas dan efisiensiya. Rasio ini dapat digunakan untuk meramalkan laba di masa depan. Ada beberapa alat ukur yang dipergunakan untuk mengukur tingkat profitabilitas, antara lain : Net Profit Margin (NPM), Return On Invesment(ROI), Return On Asset(ROA), dan Return On
Equity(ROE). Untuk mengetahui seberapa besar keuntungan (profitabilitas) yang akan dihasilkan oleh perusahaan, dalam penelitian ini profitabilitas diukur dengan menggunakan Return On Asset (ROA)/ Pengembalian laba atas aset, karena Return On Asset (ROA) merupakan rasio profitabilitas yang digunakan untuk mengukur efektivitas perusahaan dalam menghasilkan keuntungan dengan memanfaatkan total aktiva yang dimiliki. Perusahaan dapat dikatakan baik apabila rasio perbandingan antara laba bersih total aktiva cukup tinggi. Menurut Kasmir (2014:201), Return On Assets merupakan rasio yang menunjukkan hasil atas jumlah aktiva yang digunakan dalam perusahaan. Dengan mengetahui ROA, maka dapat menilai apakah perusahaan telah efisien dalammenggunakan aktivanya dalamkegiatan operasional untukmenghasilkan keuntungan.

Dalam suatu perusahaan, kas adalah investasi yang sifatnya likuid, berjangka pendek, dan dengan cepat dapat dijadikan kas dalam jumlah tertentu tanpa menghadapi resiko perubahan nilai. Kas dapat dijadikan sebagai alat ukur untuk mengetahui tingkat profitabilitas perusahaan karena kas adalah aktiva lancar yang utama dalam kegiatan operasional perusahaan.

Contohnya perusahaan farmasi, seperti : membeli mesin- mesin produksi, membeli bahan baku serta pengolahan produksinya menjadi barang jadi yang kemudian dijual untuk mendapatkan kas kembali untuk proses produksi selanjutnya. Semakin cepat perputaran kas, maka tingkat profitabilitas perusahaan menjadi baik karena proses operasional untuk menghasilkan laba berjalan dengan lancar.

Kas dan piutang memiliki pengaruh yang tinggi terhadap laba sehingga perlu penanganan yang efektif dan efisien. Tujuan dari kas adalah untuk membiayai operasi perusahaan sehari- hari maupun untuk mengadakan investasi baru dalam aktiva tetap. Tingkat perputaran kas yang tinggi menunjukkan kecepatan arus kas kembali dari kas yang telah diinvestasikan pada aktiva. Perputaran kas merupakan periode 
berputarnya kas yang dimulai saat kas diinvestasikan dalam komponen modal kerja sampai saat kembali menjadi kas-kas sebagai unsur modal kerja yang paling tinggi likuiditasnya.

Piutang juga salah satu aktiva lancar yang tidak boleh diabaikan. Adanya strategi piutang atau penjualan kredit, dapat memudahkan pelanggan dalam hal pembayaran. Pemberian piutang merupakan salah satu strategi untuk menarik pelanggan dari pesaing. Akan tetapi, adanya penjualan kredit atau piutang menimbulkan resiko piutang tak tertagih yang tidak dapat dihindarkan meskipun memungkinkan untuk diperkecil. Apabila perputaran piutang berjalan dengan lambat, maka saldo investasi dalam piutang akan menumpuk. Tingginya investasi dalam piutang juga akan menghambat aktivitas operasional perusahaan karena piutang termasuk aktiva lancar yang digunakan untuk membiayai semua kegiatan operasional perusahaan dalam tujuan untuk menghasilkan laba.

Kemampuan perusahaan dalam menghasilkan laba melalui piutang dapat dilihat dari perputaran piutangnya, jika perputaran piutang menurun maka akan berpengaruh pada kemampuan perusahaan mengembalikan investasi dalam piutang. Ketika perusahaan tidak mampu mengembalikan investasi dalam piutang menjadi kas, hal ini menunjukkan penjualan yang dilakukan secara kredit tersebut tidak memberi keuntungan bagi perusahaan, sehingga profitabilitas perusahaan pun akan menurun. Perputaran piutang (receivable turnover)

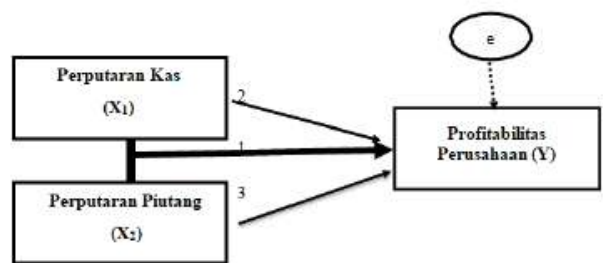

menunjukkan berapa kali suatu perusahaan melakukan tagihan atas piutangnya pada suatu periode tertentu. Kebijakan dalam pengumpulan piutang akan berhubungan dengan tingkat perputaran piutang. Semakin tinggi perputaran piutang menunjukkan masuknya kas kepada perusahaan berjalan lancar, maka dana tersebut dapat dimanfaatkan untuk aktivitas lain yang dapat memberikan keuntungan bagi perusahaan.

Menurut Nurul Pratiwi Utami, 2014

perputaran kas berpengaruh secara signifikan terhadap Return On Asset, sedangkan pada perputaran piutang tidak berpengaruh secara signifikan terhadap Return On Asset.

Menurut Vera Mustika Dewi, 2018 perputaran kas berpengaruh positif terhadap Return On Asset/ Pengembalian Laba atas Aset , sedangkan perputaran piutang tidak berpengaruh terhadap Return On Asset/ Pengembalian Laba atas Aset.

Menurut Rika Ayu Nurafika, 2018 perputaran kas berpengaruh positif signifikan terhadap Return On Asset / Pengembalian Laba atas Aset, sedangkan perputaran piutangberpengaruh negatif tidak signifikan terhadap Return On Asset.

Bertitik tolak dari pendapat yang dikemukakan di atas karena adanya perbedaan tentang pengaruh Perputaran Kas dan Perputaran Piutang terhadap profitabilitas yang diukur dengan menggunakan Return on asset, maka penulis tertarik untuk melakukan penelitian yang berjudul "PENGARUH PERPUTARAN KAS DAN PERPUTARAN PIUTANG TERHADAP PENGEMBALIAN LABA ATAS ASET / RETURN ON ASSET PADA SUB SEKTOR PERUSAHAAN FARMASI YANG TERDAFTAR DI BURSA EFEK INDONESIA ".

Adapun rumusan masalah dalam penelitian ini adalah:

1. Apakah terdapatpengaruh perputaran kas dan perputaran piutang secara simultan terhadap Return On Asset / Pengembalian laba atas aset pada Perusahaan Manafaktur Sektor Farmasi yang terdaftar di Bursa Efek Indonesia (BEI) ?

2. Apakah terdapat pengaruh perputaran kas secara parsial terhadap Return On Asset / Pengembalian laba atas aset pada perusahaan Manafaktur Sektor Farmasi yang terdaftar di Bursa Efek Indonesia (BEI) ?

3. Apakah terdapat pengaruh perputaran piutang secara parsial terhadap Return On Asset / Pengembalian laba atas aset pada Perusahaan 
Manafaktur Sektor Farmasi yang terdaftar di Bursa Efek Indonesia (BEI) ?

Adapun kerangka pemikiran dapat digambarkan sebagai berikut :

\section{Gambar 1. Kerangka Berpikir Penelitian}

\section{Hipotesis}

Berdasarkan masalah dan tujuan penelitian serta tinjauan kepustakaan maka dapat dirumuskan hipotesis penelitian adalah:

1. Diduga Perputaran Kas dan Piutang berpengaruh signifikan terhadap Pengembalian Laba Atas Aset Perusahaan Farmasi yang terdaftar di Bursa Efek Indonesia (BEI) tahun 2014-2019.

2. Diduga Perputaran Kas berpengaruh signifikan terhadap Pengembalian Laba atas Aset Perusahaan Farmasi yang terdaftar di Bursa Efek Indonesia (BEI) tahun 2014-2019

3. Diduga Piutang berpengaruh signifikan terhadap Pengembalian Laba atas Aset Perusahaan Farmasi yang terdaftar di Bursa Efek Indonesia (BEI) tahun 2014-2019

\section{B. METODE PENELITIAN}

Sumber data dalam penelitian ini adalahdata sekunder yang bersifat kuantitaif, berupa laporan keuangan tahunan perusahaan Farmasi yang terdaftar di Bursa Efek Indonesia selama enamtahun berturutturut yaitu tahun 2014- 2019 yang diperoleh dengan mengakses Indonesian Capital Market Directory (ICMD), www.idx.co.id data yangdiperoleh adalah informasi berupa laporan keuangan yang berhubungan dengan variabel penelitian dan literatur- literatur yang berhubungan dengan masalah yang diteliti.

\section{Populasi}

Menurut Zuriah (2009:116) Populasi adalah seluruh data yang menjadi perhatian peneliti dalam suatu ruang lingkup dan waktu yang telah ditentukan. Adapun populasi dalam penelitian ini adalah perusahaan farmasi yang terdaftar Di Bursa Efek Indonesia yang berjumlah 6 perusahaan.

Adapun cara pengambilan sampel dalam penelitian ini adalah dengan menggunakan purposive sampling. purposive sampling menurut Sugiyono, (2012 : 85) yaitu : purposive sampling adalah teknik pengambilan sampel sumber data dengan pertimbangan tertentu. Sedangkan menurut Efferin Sujoko (2012:86) purposive sampling adalah metode penetapan sample dengan cara menentukan target dari elemen populasi yang diperkirakan paling cocok untuk dikumpulkan datanya. Berdasarkan pengertian purposive sampling menurut para ahli diatas, maka untuk menentukan sample dalam penelitian ini harus berdasarkan kriteria- kriteria yang cocok untuk dikumpulkan datanya. Kriteria-kriteria dalam penelitian ini adalah sebagai berikut :

1. Perusahaan Farmasi yang sudah terdaftar di Bursa Efek Indonesia sejak 2014 sampai 2019

2. Laporan keuangan perusahaan Farmasi tersebut sudah diaudit.

3. Perusahaan Farmasi tersebut mempunyai data mengenai perputaran kas dan perputaran piutang 
Tabel 1. Daftar Perusahaan Farmasi yang Terdaftar di Bursa Efek Indonesia Tahun 2014 - 2020

\begin{tabular}{|c|c|c|c|}
\hline No & Kode Perusahaan & Nama Perusahaan & Sampel \\
\hline 1 & KAEF & PT. Kimia Farma Tbk. & $\square$ \\
\hline 2 & KLBF & PT. Kalbe Farma Tbk. & $\square$ \\
\hline 3 & PYFA & PT. Pyridam Farma Tbk. & $\square$ \\
\hline 4 & DVLA & PT. Darya-Varia Laboratoria Tbk. & $\times$ \\
\hline 5 & INAF & PT. Indofarma Persero Tbk. & $\times$ \\
\hline 6 & SIDO & $\begin{array}{c}\text { PT. Industri Jamu dan Farmasi } \\
\text { Sido Muncul Tbk. }\end{array}$ & $\square$ \\
\hline 7 & TSPC & PT. Tempo Scan Pacific Tbk. & $\square$ \\
\hline 8 & MERK & PT. Merck Tbk. & $\square$ \\
\hline 9 & SCPI & PT. Merck Sharp Dohme Pharma & $\times$ \\
\hline 10 & PEHA & PT. Phapros Tbk. & $\times$ \\
\hline
\end{tabular}

Berdasarkan tabel maka farmasi yang terdaftar di BEI yang masuk kedalam kriteria penentuan sample hanya ada 6 perusahaan yaitu PT. Kimia Farma Tbk, PT. Kalbe Farma Tbk, PT Industri Jamu dan Farmasi Sido Muncul Tbk, PT. Tempo Scan Pacific Tbk, PT. Merck Tbk. dengan laporan keuangan 6 periode, jadi sample dalam penelitian ini adalah sebanyak 36 sampel. Prosedur pengumpulan data dalam penelitian ini adalah sebagai berikut: Studi pustaka dan studi lapangan, studi pustaka dilakukan dengan cara mempelajari buku- buku, jurnaljurnal, situs internet, dan karya tulis lainnya yang berhubungan dengan masalah yang diteliti. Sedangkan studi lapangan dilakukan dengan mengumpulkan data secara tidak langsung terhadap objek dengan alat atau cara tertentu yang bersumber dari pihak kedua atau melalui media perantara. Penelitian lapangan dalam penelitian ini berupa data laporan keuangan perusahaan farmasi yang terdaftar di Bursa Efek Indonesia yang nantinya akan diolah untuk dapat digunakan sebagai variabel penelitian. Data penelitian didapatkan dari website IDX yaitu : www.idx.co.id Dalammenguji variabel - variabel yang digunakanuntuk penelitian ini penulis di bantu oleh software statistik yaitu program SPSS (Statistical Package for Social Sciences).

\section{HASIL DAN PEMBAHASAN}

\subsection{Hasil Penelitian}

\section{Uji Prasyarat Analisis dan Asumsi Klasik} Uji Normalitas

Uji normalitas bertujuan untuk menguji sebuah model regresi, variabel dependen, variabel independen atau keduanya berdistribusi normal atau tidak.

Tabel 2. Uji Normalitas One-Sample Kolmogorov-Smirnov Test

\begin{tabular}{llr}
\hline $\mathrm{N}$ & & 36 \\
\hline Normal Parameters $^{\mathrm{a}, \mathrm{b}}$ & Mean & .0000000 \\
\cline { 2 - 3 } & Std. Deviation & 5.37899463 \\
\hline Most Extreme Differences & Absolute & .133 \\
& Positive & .133 \\
\cline { 2 - 3 } & Negative & -.074 \\
\hline Test Statistic & & .133 \\
\hline Asymp. Sig. (2-tailed) & & $.106^{c}$ \\
\hline
\end{tabular}


a. Test distribution is Normal.

b. Calculated from data.

c. Lilliefors Significance Correction.

d. This is a lower bound of the true significance.

Sumber : Lampiran SPSS 24, data diolah (tahun 2020)

Dari hasil output pada tabel 2 dapat diketahui bahwa nilai Asymp.Sig. (2-tailed) sebesar 0.106. Karena nilai signifikasi lebih dari 0,05 maka nilai residual antara variabel Perputaran Kas dan Perputaran Piutang terhadap Pengembalian Laba atas Aset terdistribusi dengan normal atau data pada penelitian ini terdistribusi normal. Dengan catatan mulai SPSS versi 24.

\section{Uji Multikolinearitas}

Uji multikolinearitas merupakan uji asumsi yang digunakan untuk mengetahui apakah pada model regresi terdapat ada atau tidaknya korelasi antar indepen dan dependent $(\mathrm{X})$. Hasil pengujian yang baik adalah tidak terdapat multikolinearitas

Tabel 3. Uji Multikolinearitas

\begin{tabular}{|c|c|c|c|c|c|c|c|c|}
\hline & & & oefficients ${ }^{\mathrm{a}}$ & & & & & \\
\hline $0 ; 1$ & $\begin{array}{r}\text { Unstanda } \\
\text { Coeffici }\end{array}$ & $\begin{array}{l}\text { dized } \\
\text { ants }\end{array}$ & $\begin{array}{l}\text { Standardized } \\
\text { Coefficients }\end{array}$ & & & Collinea & y Stat & istics \\
\hline Model & B & $\begin{array}{l}\text { Std. } \\
\text { Error }\end{array}$ & Beta & $\mathrm{t}$ & Sig. & Tolerance & & IF \\
\hline 1 & (Constant) & 14.473 & 2.928 & & 4.942 & \begin{tabular}{l|l}
2 & .000
\end{tabular} & & \\
\hline & $\begin{array}{l}\text { Perputaran } \\
\text { Kas }\end{array}$ & .165 & .305 & .098 & .542 & .591 & .897 & 1.115 \\
\hline & $\begin{array}{l}\text { Perputaran } \\
\text { Piutang }\end{array}$ & .496 & .481 & .187 & $\begin{array}{ll}7 & 1.032\end{array}$ & .310 & .897 & 1.115 \\
\hline
\end{tabular}

Dependent Variable: ROA/Pengembalian laba atas aset

Berdasarkan hasil output pada tabel 3 diketahui bahwa nilai VIF yang diperoleh sebesar $1,115<10$ dan nilai Tolerance kedua variabel lebih dari 0,1 yaitu sebesar 0,897 maka dapat disimpulkan bahwa tidak terjadi multikolinieritas antar variabel bebas.

\section{Uji Autokorelasi}

Uji autokorelasi dilakukan untuk mengetahui apakah dalam sebuah model regresi linier terdapat hubungan yang kuat baik positif maupun negatif antar data yang ada pada variabel-variabel penelitian. Untuk memeriksa ada tidaknya autokorelasi, maka digunakan pendekatan Uji Durbin-Watson (d). Pengambilan keputusan pada uji Durbin Watson sebagaiberikut:

1. Jika statistik DW bernilai -2, berarti ada autokolerasi positif.

2. Jika statistik DW bernilai -2 sampai +2 , berarti tidak ada autokolerasi.

3. Jika statistik DW bernilai +2 , berarti ada autokolerasi negative.

Berikut hasil pengujian autokorelasipada penelitian ini yang menggunakan pendekatan Uji Durbin Watson.

\section{Tabel 4. Uji Autokorelasi}


Jurnal Kompetitif, Vol. 10, No. 1, hal. 01 - 14, Edisi Januari 2021

p-ISSN 2302-4585; e-ISSN 2721-3765

Model Summary ${ }^{\mathrm{b}}$

\begin{tabular}{rl|r|r|r|r}
$\begin{array}{l}\text { Mo } \\
\text { del }\end{array}$ & $\mathrm{R}$ & R Square & $\begin{array}{c}\text { Adjusted R } \\
\text { Square }\end{array}$ & $\begin{array}{c}\text { Std. Error of the } \\
\text { Estimate }\end{array}$ & Durbin-Watson \\
\hline 1 & $.422^{\mathrm{a}}$ & .178 & .128 & 1.81626 & 1.185 \\
\hline \multicolumn{5}{c}{$\begin{array}{l}\text { a. Predictors: (Constant), Perputaran Piutang, Perputaran Kas } \\
\text { b. Dependent Variable: ROA / pengembalian laba atas aset }\end{array}$}
\end{tabular}

Sumber : Lampiran SPSS 24, data diolah (tahun 2020)

Dari hasil output diatas pada tabel 4 dapat diketahui bahwa nilai Durbin Watson yang diperoleh sebesar 1,185 nilai Durbin Watson berada diantara-2 dan +2 yang artinya tidak terjadi autokolerasi.

\section{Uji Heteroskedastisitas}

Tujuan dari uji heteroskedastisitas yaitu untuk mengetahui ada tidaknya ketidaksamaan varian dan residual dari pengamatan-pengamatan yang dilakukan. Pada regresi yang baik seharusnya tidak terjadi heteroskedastisitas. Pada penelitian ini, metode yang digunakan adalah metode uji Glejser. Pengujian dengan menggunakan metode Glejser yaitu meregresikan variabel independen dengan nilai absolute residualnya. Jika nilai absolute residual yang didapat lebih dari 0,05 maka dapat dikatakan bahwa tidak terjadi masalah heteroskedastisitas. Untuk hasil pengujian pada penelitian ini dengan menggunakan metode Glejser yaitu sebagai berikut :

\section{Tabel 5. Uji Heteroskedastisitas}

\begin{tabular}{|c|c|c|c|c|c|c|}
\hline \multicolumn{7}{|c|}{ Coefficients $^{a}$} \\
\hline \multirow{2}{*}{\multicolumn{2}{|c|}{ Model }} & \multicolumn{2}{|c|}{ Unstandardized Coefficients } & \multirow{2}{*}{$\begin{array}{c}\begin{array}{c}\text { Standardized } \\
\text { Coefficients }\end{array} \\
\text { Beta }\end{array}$} & \multirow[b]{2}{*}{$\mathrm{t}$} & \multirow[b]{2}{*}{ Sig. } \\
\hline & & $\mathrm{B}$ & Std. Error & & & \\
\hline \multirow[t]{3}{*}{1} & (Constant) & 5.399 & 1.538 & & 3.511 & .001 \\
\hline & Perputaran Kas & .077 & .160 & .087 & .478 & .636 \\
\hline & Perputaran Piutang & .079 & .253 & .057 & .314 & .755 \\
\hline
\end{tabular}

Sumber : Lampiran SPSS 24, data diolah (tahun 2020)

Dari hasil output pada tabel 5. dapat diketahui yaitu pada variabel Perputaran Kas (X1) yang disimbolkan dengan ABS_RES1 nilai signifikansi lebih besar dari 0,05 $(0,636>0,05)$. Perputaran Piutang (X2) nilai signifikansi lebih besar dari 0,05 $(0,755>0,05)$. Dari nilai-nilai tersebut dapat disimpulkan bahwa tidak terjadi masalah heteroskedastisitas pada model regresi dalam penelitian ini.

\section{Analisis Rigresi Linier Berganda}

Dalam penelitian ini menggunakan model regresi linier berganda yang digunakan untuk menguji pengaruh antar variabel independen (X) terhadap variabel dependen (Y). Adapun persamaan yang digunakan pada regresi linier berganda :

\section{Tabel 6. Analisis Regresi Linier Berganda}


Jurnal Kompetitif, Vol. 10, No. 1, hal. 01 - 14, Edisi Januari 2021

p-ISSN 2302-4585; e-ISSN 2721-3765

\begin{tabular}{|c|c|c|c|c|c|}
\hline \multirow{2}{*}{$\begin{array}{l}\text { Coefficients }^{a} \\
\text { Model } \\
\end{array}$} & \multicolumn{2}{|c|}{ Unstandardized Coefficients } & \multirow{2}{*}{$\begin{array}{c}\text { Standardized } \\
\text { Coefficients } \\
\text { Beta } \\
\end{array}$} & \multirow[b]{2}{*}{$\mathrm{t}$} & \multirow[b]{2}{*}{ Sig. } \\
\hline & $\mathrm{B}$ & Std. Error & & & \\
\hline (Constant) & 8.586 & 1.165 & & 7.371 & .000 \\
\hline Perputaran Kas & .379 & .179 & .353 & 2.118 & .042 \\
\hline Perputaran Piutang & .373 & .173 & .358 & 2.150 & .039 \\
\hline
\end{tabular}

a. Dependent Variable: ROA / pengembalian laba atas aset

Berdasarkan tabel 6. persamaan regresi linier berganda yang dihasilkan dan ditentukan dengan nilai-nilai yang tercantum pada kolom B yaitu:

$\mathrm{Y}=8,586+(0,379) \mathrm{X} 1+(0,373)$

$\mathrm{X} 2+\mathrm{e}$

Dari persamaan tersbut maka disimpulkan sebagai berikut:

- Nilai konstanta (a) adalah 8,586 artinya bahwa jika Perputaran Kas, Perputaran Piutang dan Return On Asset (ROA) / Pengembalian laba atas aset diasumsikan tidak berubah atau pada kondisi konstanta bernilai 0, maka rata-rata Return On Asset atau pengembalian laba atas aset pada perusahaan Farmasi yang terdaftar di Bursa Efek Indonesia akan bernilai 8,586

- Nilai koefisien regresi variabel Perputaran Kas (b1) bernilai Positifsebesar 0,379 artinya bahwa Perputaran Kas berbanding lurus dengan Return On Asset/Pengembalian laba atas aset pada perusahaan Farmasi yang terdaftar di Bursa Efek Indonesia. ApabilaPerputaran Kas mengalami peningkatan satu persen sedangkan variabel lainnya tidak mengalami perubahan atau konstan, maka Return On Asset akan naik sebesar 0,379. Dengan demikian dapat dikatakan bahwa industri dengan nilai Perputaran kas yang tinggi cenderung memiliki tingkat pegembalian asetnya tinggi.

- Nilai koefisien regresi variabel
Perputaran Piutang (b2) bernilai positif sebesar 0,373 artinya bahwa Perputaran Piutang berbanding lurus dengan Pengembalian laba atas aset pada perusahaan Farmasi yang terdaftar di Bursa Efek Indonesia. Apabila Perputaran piutang mengalami peningkatan satu kali dengan asumsi variabel lainnya tidak mengalami perubahan atau konstan, maka pengembalian laba atas aset akan naik sebesar 0,373. Artinya perusahaan yang nilai perputaran piutang tinggi maka akan mengalami peningkatan dalam hal pengembalian laba atas aset .

\section{Koefisien Korelasi}

Koefisien kolerasi adalah nilai yang menunjukkan kuat atau tidaknya hubungan linier antara dua variabel. Koefisien kolerasi biasa dilambangkan dengan huruf $r$ dimana nilai $r$ dapat bervariasi dari -1 sampai +1 . Nilai $r$ yang mendekati -1 atau +1 menunjukkan hubungan yang kuatantara dua variabel tersbut. Sedangkan tanda + (positif) dan - (negatif) memberikan informasi mengenai arah hubungan antara dua variabel tersebut. Jika benilai positif maka kedua variabel tersebut memiliki hubungan yang searah. Jika bernilai negatif artinya kolerasi antara kedua variabel tersebut bersifat berlawanan.

\section{Tabel 7. Koefisien Korelasi}




\section{Correlations}

\begin{tabular}{|c|c|c|c|c|}
\hline & & $\begin{array}{c}\text { Perputaran } \\
\text { Kas }\end{array}$ & $\begin{array}{c}\text { Perputaran } \\
\text { Piutang } \\
\end{array}$ & $\begin{array}{c}\text { ROA / } \\
\text { pengembalia } \\
\text { n laba atas } \\
\text { aset }\end{array}$ \\
\hline \multirow[t]{3}{*}{ Perputaran Kas } & Pearson Correlation & 1 & .308 & .241 \\
\hline & Sig. (2-tailed) & & .068 & .156 \\
\hline & $\mathrm{N}$ & 36 & 36 & 36 \\
\hline \multirow[t]{3}{*}{ Perputaran Piutang } & Pearson Correlation & .308 & 1 & .256 \\
\hline & Sig. (2-tailed) & .068 & & .132 \\
\hline & $\mathrm{N}$ & 36 & 36 & 36 \\
\hline \multirow{3}{*}{$\begin{array}{l}\text { ROA / } \\
\text { pengembalian laba } \\
\text { atas aset }\end{array}$} & Pearson Correlation & .241 & .256 & 1 \\
\hline & Sig. (2-tailed) & .156 & .132 & \\
\hline & $\mathrm{N}$ & 36 & 36 & 36 \\
\hline
\end{tabular}

Sumber : Lampiran SPSS 24, data diolah (tahun 2020)

Dari tabel 7. dapat dilihat adanya hubungan (korelasi) yang rendah antara Perputaran Kas terhadap Return On Asset/ Pengembalian laba atas aset yaitu sebesar 0,241 dan memiliki arah positif yang artinya apabila Perputaran Kas meningkat maka Return On Asset / Pengembalian labaatas aset meningkat. Adanya hubungan (korelasi) antara Perputaran Piutang terhadap Return On Asset/ Pengembalian laba atas aset didapat nilai koefisien sebesar 0,256. Karena koefisien terletak pada rentang $0,20-0,399$ maka dapat disimpulkan bahwa Perputaran Piutang terhadap Return On Asset/ Pengembalian laba atas aset memiliki hubungan yang rendah dan memiliki arah positif yang artinya apabila Perputaran Piutang meningkat maka Return On Asset/ Pengembalian laba atas aset akanmeningkat.

\section{Uji Hipotesis}

Uji F

Uji pengaruh simultan digunakan untuk mengetahui apakah variabel independen secara bersama-sama atau simultan mempengaruhi variabel dependen. Uji $F$ dilakukan untuk menguji hipotesis, langkah - langkah yang dilakukan sebagai berikut:

a. Merumuskan hipotesis statistik:
$\mathrm{H} 0: \mathrm{b} 1 \mathrm{~b} 2=0$, artinya variabel Perputaran Kas dan Perputaran Piutang dimana menjadi variabel bebas secara bersama - sama tidak berpengaruh terhadap variabel Return On Assets dimana menjadi variabel terikat.

1. Ha : $\mathrm{b}_{1} \mathrm{~b} 2 \neq 0$, artinya variabel Perputaran Kas dan Perputaran Piutang dimana menjadi variabel bebas secara bersama - sama berpengaruh terhadap variabel Return On Assets dimana menjadi variabel terikat.

2. Ha : $\mathrm{b} 1 \mathrm{~b} 2 \neq 0$, artinya variabel Perputaran Kas dan Perputaran Piutang dimana menjadi variabel bebas secara bersama - sama berpengaruh terhadap variabel Return On Assets dimana menjadi variabel terikat.

b. Menentukan tingkat signifikansi: taraf signifikansi adalah $95 \%$ atau $\alpha=5 \%$ $(0,05)(\alpha 2)$

c. Kriteria pengujian:

1. Jika F Sig $\geq 0,05$ maka $\mathrm{H} 0$ diterima, $\mathrm{Ha}$ ditolak

2. Jika F Sig < 0,05 maka H0 ditolak, Ha diterima

\section{Tabel 8 Uji F}




\section{ANOVA $^{a}$}

\begin{tabular}{l|r|r|r|r|r} 
Model & Sum of Squares & df & Mean Square & F & Sig. \\
\hline 1 Regression & 23.620 & 2 & 11.810 & 3.580 & $.039^{b}$ \\
\hline Residual & 108.860 & 33 & 3.299 & & \\
\hline Total & 132.480 & 35 & & & \\
\hline
\end{tabular}

a. Dependent Variable: ROA / pengembalian laba atas aset Predictors: (Constant), Perputaran Piutang, Perputaran Kas

Dari hasil output pada tabel 8 diketahui nilai $\mathrm{F}$ hitung yang diperoleh sebesar 3,580 dengan signifikansi 0,039. Untuk menentukan nilai pada $\mathrm{F}$ tabeldengan melihat pada tabel statistik (lihat lampiran) pada tingkat signifikansi 0,05 dengan df $1=$ 2 , dan df 2 (n-k-1) atau 36-2-1 = 33, hasil yang diperoleh untuk $\mathrm{F}$ tabel sebesar 3,580. Dengan nilai $\mathrm{F}$ hitung yang lebih besar dari $\mathrm{F}$ tabel yaitu 3,580 > 3,280 dan signifikansi lebih kecil $(0,039<0,05)$ maka H0 ditolak. Artinya bahwa Perputaran Kaas dan Perputaran Piutang secara bersama-sama berpengaruh terhadap Return On Asset atau Pengembalian laba terhadap asset.

\section{Uji t}

Uji parsial digunakan untuk mengetahui pengaruh masing-masing variabel independen terhadap variabel dependen.

Dasar pengambilan keputusan uji $t$ penelitian ini yaitu sebagai berikut:

a. Jika t Sig $\geq 0,05$ maka $\mathrm{H}_{0}$ diterima, $\mathrm{Ha}_{\mathrm{a}}$ ditolak

b. Jika t Sig < 0,05 Maka H0 ditolak, Ha diterima

Uji $t$ dilakukan untuk menguji hipotesis, langkah - langkah yang dilakukan sebagai berikut:

1. Pengaruh Perputaran Kas terhadap Return on assets/ Pengembalian laba

\begin{tabular}{|c|c|c|c|c|c|c|}
\hline \multirow{2}{*}{\multicolumn{2}{|c|}{ Model }} & \multicolumn{2}{|c|}{ Unstandardized Coefficients } & \multirow{2}{*}{$\begin{array}{c}\text { Standardized } \\
\text { Coefficients } \\
\text { Beta }\end{array}$} & \multirow[b]{2}{*}{$\mathrm{t}$} & \multirow[b]{2}{*}{ Sig. } \\
\hline & & $\mathrm{B}$ & Std. Error & & & \\
\hline \multirow[t]{3}{*}{1} & (Constant) & 8.586 & 1.165 & & 7.371 & .000 \\
\hline & Perputaran Kas & .379 & .179 & .353 & 2.118 & .042 \\
\hline & Perputaran Piutang & .373 & .173 & .358 & 2.150 & .039 \\
\hline
\end{tabular}

a. Dependent Variable: ROA / pengembalian laba atas aset

terhadap aset

a. $\mathrm{H}_{0}: \mathrm{b}_{1}=0$, artinya tidak ada pengaruh Perputaran Kas terhadap Return on assets / Pengembalian laba terhadap aset pada perusahaan farmasi yangterdaftar di Bursa Efek Indonesia.

b. $\mathrm{H}_{\mathrm{a}}: \mathrm{b} 1 \neq 0$, artinya terdapat pengaruh Perputaran Kas terhadap Return on assets / pengembalian laba terhadap aset pada perusahaan farmasi yangterdaftar di Bursa Efek Indonesia.

2. Pengaruh Perputaran Piutang terhadap Return on assets / pengembalian laba terhadap aset

a. $\mathrm{H}_{0}: \mathrm{b}_{1}=0$, artinya tidak ada pengaruhPerputaran Piutang terhadap Return on assets / Pengembalian laba terhadap aset pada perusahaan farmasi yang terdaftar di Bursa Efek Indonesia.

b. $\mathrm{H}_{\mathrm{a}}: \mathrm{b}_{1} \neq 0$, artinya terdapat pengaruh Perputaran Piutang terhadap Return on assets / pengembalian labaterhadap aset pada perusahaan farmasi yang terdaftar di Bursa Efek Indonesia

\section{Tabel 9. Uji t}

http://univ-tridinanti.ac.id/ejournal/index.php/ekonomi/index 
Berdasarkan pada tabel 9 . maka dapat diketahui bahwa:

- Hasil pengujian hipotesis menunjukkan bahwa Perputaran Kas memiliki nilai thitung sebesar 2,118 dengna nilai Signifikansi sebesar 0,042. ttabel dapat dilihat pada tabel statistik (lampiran) pada signifikansi 0,05 dengan derajat kebebasan $\mathrm{df}=\mathrm{n}$ k-1 (36-2-1 = 33) maka hasil yang diperoleh untuk $\mathrm{t}$ tabel sebesar 1,693 dengan nilai t hitung lebih besar dari pada t tabel $(2,118>1,693)$ dan nilai signifikansi lebih kecil dari 0,05 $(0,042<0,05)$ maka dapat disimpulkan H0 ditolak. Artinya bahwa Perputaran Kas secara parsial berpengaruh terhadap Return on asset / Pengembalian laba terhadap aset. Nilai thitung positif artinya berpengaruh positif.

- Hasil pengujian hipotesis menunjukkan bahwa Perputaran Kas memiliki nilai thitung sebesar 2,150 dengna nilai Signifikansi sebesar 0,039. ttabel dapat dilihat pada tabel statistik (lampiran) pada signifikansi 0,05 dengan derajat kebebasan $\mathrm{df}=\mathrm{n}$ k-1 (36-2-1 = 33) maka hasil yang diperoleh untuk $\mathrm{t}$ tabel sebesar 1,693 dengan nilai t hitung lebih besar dari pada t tabel $(2,150>1,693)$ dan nilai signifikansi lebih kecil dari 0,05 $(0,039<0,05)$ maka dapat disimpulkan HO ditolak. Artinya bahwa Perputaran Piutang secara parsial berpengaruh terhadap Return on asset / Pengembalian laba terhadap aset. Nilai thitung positif artinya berpengaruh positif.

\section{Koefisien Determinasi $\left(\mathbf{R}^{2)}\right.$}

Sugiyono (2013:231) koefisien determinasi digunakan untuk mengetahui uraian yang dapat diterangkan oleh persamaan regresi yaitu untuk mengetahui seberapa besar variabel $\mathrm{Y}$ yang dapat diterangkan oleh variabel bebas.

\section{Tabel 10. Koefisien Determinasi}

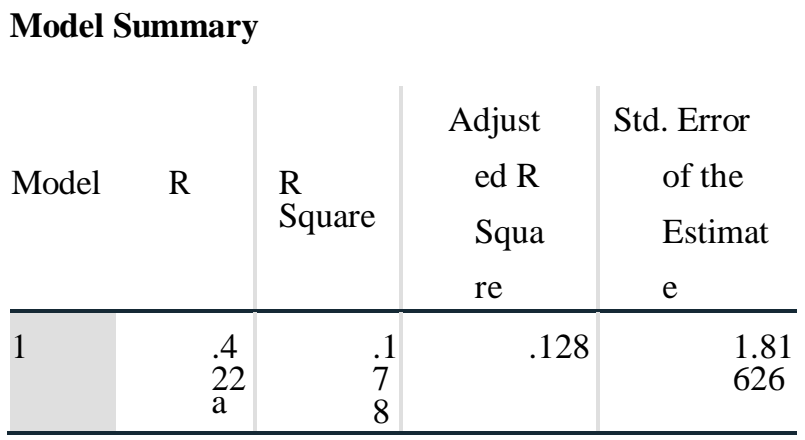

a. Predictors: (Constant), Perputaran Piutang, Perputaran Kas

b. Dependent Variable: ROA / pengembalian laba atas aset

Sumber:Lampiran SPSS 24, data diolah (tahun 2020)

Berdasarkan hasil output pada tabel 10 diketahui bahwa nilai $\mathrm{R}$ Square yang diperoleh sebesar 0,178 atau 17,8\%. Artinya kontribusi variabel Perputaran Kas (X1) dan Perputaran Piutang (X2) mempengaruhi variabel Return On Asset I Pengembalian laba atas aset (Y) hanya sebesar $17,8 \%$ dan sisanya $82,2 \%$ dipengaruhi oleh variabel lain yang tidak termasuk dalam penelitian ini seperti Perputaran Piutang, Perputaran Piutang dan Return on asset / Pengembalian laba atas aset.

\subsection{Pembahasan}

Pengaruh Perputaran Kas dan Perputaran Piutang secara simultan terhadap Return on asset/pengembalian laba atas aset pada perusahaan sektor farmasi yang terdaftar di Bursa Efek Indonesia.

Pada penelitian ini terdapat hubungan antara Perputaran Kas dan PerputaranPiutang terhadap Return On Asset / Pengembalian laba atas aset. Besae kecilnya Perputaran kas dan Perputaran piutang itu mempengaruhi Return on asset / pengembalian laba terhadap aset perusahaan. Hal ini dibuktikan dari ada pengujian $\mathrm{F}$ thitung lebih besar dari Ftabel (3,580 > 
$3,280)$ dan signifikan lebih kecil dari 0,05 $(0,039<0,05)$ maka $\mathrm{H} 0$ ditolak $\mathrm{Ha}$ diterima. Artinya bahwa Perputaran kas dan Perputran piutang secara simultan berpengaruh terhadapReturn on asset / pengembalian laba atas aset. Hal ini sejalan dengan hipotesis yang dinyatakan bahwa Perputaran Kas dan Perputaran Piutang berpengaruh secara bersama - sama terhadap Return On Asset/ Pengembalian laba terhadap aset.

\section{Pengaruh Perputaran Kas Terhadap Return on asset / Pengembalian labaterhadap aset pada perusahaan farmasi yang terdaftar di Bursa Efek Indonesia.}

Pengaruh Perputaran Kas terhadap

Return on asset / Pengembalian laba terhadap aset berdasarkan hasil pengujian uji tbahwa nilai thitung lebih besar dari pada ttabel $(2,118>1,693)$ dan nilai signifikansi lebih kecil dari $0,05(0,042<0,05)$ maka dapat disimpulkan $\mathrm{H} 0$ ditolak dan $\mathrm{Ha}$ diterima. Artinya Perputaran Kas berpengaruh secara parsial terhadap Return on asset / Pengembalian laba terhadap aset. Hasil penelitian ini menunjukan bahwa perputaran Kas mempunyai nilai thitung positif sebesar 2, 118 hal inimenunjukkan bahwa perputaran kas berpengaruh secara positif dan signifikan terhadap Return On asset / Pengembalian laba terhadap aset perusahaan farmasi yang terdaftar di BEI periode 2014- 2019. Semakin baik perputaran kas maka akan semakin tinggi Pengembalian laba terhadap aset suatu perusahaan, begitu juga sebaliknya jika perputaran kas kurang baik, maka pengembalian laba terhadap aset suatu perusahaan akan semakin menurun.

Hasil penelitian ini sesuai dengan penelitian yang dilakukan oleh Utami dan Dewi (2016) yang menyatakan bahwa tingkat perputaran kas berpengaruh positif dan signifikan terhadap profitabilitas, Putri Ayu Diana (2016) menunjukkan perputaran kas berpengaruh signifikan terhadap profitabilitas dan Mohamad Tejo Suminar (2015) Menyatakan Bahwa Perputaran kas berpengaruh signifikan terhadap profitabilitas.

Adanya pengaruh yang positif berarti bahwa semakin tinggi perputaran kas maka keuntungan yang diperoleh perusahaan juga akansemakin tinggi dengan jumlah kas tertentu yang dimiliki perusahaan, akan menghasilkan penjualan yang tinggi.Tingkat penjualan yang tinggi akan menyebabkan keuntungan yang diperoleh perusahaan semakin tinggi. Hal inimenunjukkan perusahaan telah menggunakan kas secara efisien.

\section{Pengaruh Perputaran Piutang Terhadap Return on asset / Pengembalian laba terhadap aset pada perusahaan farmasi yang terdaftar di Bursa Efek Indonesia.}

Dari analisis yang telah dilakukan, dapat diperoleh perputaran piutang secara individual berpengaruh positif dan signifikan terhadap profitabilitas pada perusahaan farmasi yang terdaftar di BEI. Uji regresi yang telah dilakukan menunjukkan besaran signifikan untuk variabel perputaran piutang adalah $0,039<0,05$. Selain itu uji $t$ menunjukkan thitung sebesar $2,150<\mathrm{t}$ table 1,693. Hal ini berarti sesuai dengan hipotesis. Hal ini dapat disebabkan karena perusahaan mampu memperkirakan piutang yang mungkin tidak tertagih dengan baik serta perusahaan mampu meminimalisir kredit macet sehingga perputaran piutang pun tidak terganggu dan perusahaan dapat tetapmemperoleh profit.

Menurut Budiansyah, dkk (2016), jika mengelola perputaran piutang secara efektif, maka akan berdampak positif pada profitabilitas karena semakin tinggi tingkat rasio perputaran piutang, maka akan semakin baik karena jumlah piutang tidak tertagih semakin sedikit serta tidak terjadinya over investment dalam piutang. Dengan begitu semakin cepat pula kas masuk bagi perusahaan dari penagihan piutang, sehingga kas dapat digunakan kembali untuk kegiatan operasional perusahaan, berdampak pada aktivitas penjualan serta profitabilitas akan meningkat. Dengan hasil penelitian ini, menunjukkan bahwa perputaran piutang berpengaruh positif yang signifikan terhadap profitabilitas perusahaan, sesuai dengan hasil penelitian yang diteliti oleh Julita (2012), 
Mohamad Tejo Suminar (2015) perputaran piutang berpengaruh positif terhadap profitabilitas (ROA maupun ROE) Dan Herpina Hera Rezeki (2018) perputaran piutang dengan profitabilitas berpengaruh positif dan signifikan, dimana setiap kenaikan piutang akan dapat meningkatkan profitabilitas

\section{SIMPULAN DAN SARAN 4.1. Simpulan}

Berdasarkan hasil penelitian dan pembahasan pada bab sebelumnya, maka dapat ditarik kesimpulan sebagai berikut:

1. Perputaran Kas dan Perputaran Piutang berpengaruh secara Simultan terhadap Return On Asset/Pengembalian laba terhadap aset. Hal tersebut sejalan dengan hipotesis yang dibuat peneliti dimana hasil yang diperoleh bahwa nilai $\mathrm{F}$ hitung lebih besar dari $\mathrm{F}$ tabel $(3,580>3,280)$ dan signifikansi lebih kecil $(0,039<$ $0,05)$.

2. Perputaran Kas secara parsial berpengaruh terhadap Return on asset/Pengembalian laba terhadap aset. Hal ini dibuktikan oleh nilai thitung lebih besar dari ttabel $(2,118>1,693)$ dan nilai signifikan lebih kecil dari $0,05(0,042<0,05)$ maka H0 ditolak dan Ha diterima.

3. Perputaran Piutang secara parsial berpengaruh terhadap Return on asset/Pengembalian laba terhadap aset. Hal ini dibuktikan oleh nilai thitung lebih besar dari ttabel $(2,150>1,693)$ dan nilai signifikan lebih kecil dari 0,05 $(0,039<0,05)$ maka $\mathrm{H} 0$ ditolak dan Ha diterima.

4. Perputaran kas punya pengaruh yang lebih dominan dari perputaran piutang

\subsection{Saran}

Berdasarkan dari hasil penelitian yang dilakukan, penulis memberikan beberapa saran yaitu:

1. Bagi Perusahaan
Perusahaan hendaknya lebih memperhatikan lagi pengelolaan kas yang dimilikinya dengan lebih meningkatkan perputaran kas dan meminimalkan kas menganggur yang dapat dilakukan dengan cara meningkatkan volume penjualan melalui kegiatan promosi dan lebih meningkatkan kinerja orang penagihan piutang dengan cara mengingatkan debitur untuk segera melunasi Hutangnya agar hutang tersebut bisa menjadi kas dan dapat diolah kembali. Dengan demikian, tingkat keuntungan yang diperoleh perusahaan akan meningkat. Rasio ini sangat penting bagi perusahaan karena menggambarkan kemampuan perusahaan dalam menghasilkan laba dengan menggunakan seluruh asset yang ada. Oleh sebab itu, pihak manajemen perusahaan diharapkan lebih memperhatikan dan meningkatkan lagi rasio Return On Asset yaitu dengan meningkatkan volume penjualan, melakukan penghematan biaya operasional dan mengurangi atau mempertahankan aktiva (asset) yang dimiliki perusahaan serta lebih memperhatikan komponen lain yang dapat mempengaruhi tingkat keuntungan bagi perusahaan. Dengan demikian, tingkat profitabilitas dalam rasio ROA dapat meningkat.

2. Bagi Peneliti Selanjutnya

Diharapkan peneliti selanjutnya dapat meneliti Perputaran Kas dan Perputaran Piutang dengan standar pengukuran yang berbeda dari penelitian ini,serta diharapkan dapat meneliti variabel-variabel lain selain Perputaran Kas dan Perputaran Piutang, karena terdapat faktor-faktor lain yang dapat mempengaruhi Return on asset (ROA). Selain itu, penulis menyarankan untuk menambah periode tahun yang akan diteliti dan menambah objek.

\section{E. DAFTAR RUJUKAN}

Andi Prastowo. (2011). Metode Penelitian Kualitatif dalam Perspektif Rancangan Penelitian. Jogjakarta: Ar-Ruzz Media.

Asna Lestari, 2016. Analisis Perputaran Piutang dan Perputaran Persediaan serta Pengaruhnya terhhadap Profitabilitas Perusahan Otomotif yang Terdaftar di Bursa Efek 
Indonesia diakses pada tanggal 08 juli 2020 pukul 19.55

Bambang Riyanto. 2011, "Dasar -Dasar Pembelanjaan Perusahaan", Edisi Keempat, Cetakan Ketujuh, Yogyakarta : YBPFE UGM.

Dewi, Vera Mustika. “ Pengaruh Perputaran Modal Kerja, Perputaran Piutang dan Perputaran Kas Terhadap Profitabilitas Perusahan (Studi pas Perusahaan Konstruksi Sektor Infrastruktur di Bursa Efek Indonesia Periode 2012-2015. Volume 2 Nomor 2, 2017 https://scholar.google.co.id Diakses pada bulan Juni 2020.

Dwi Martani, dkk. 2014. Akuntansi Keuangan Menengah Berbasis PSAK. Jakarta: Salemba Empat.

Fahmi, Irham. 2011. Analisis Laporan Akuntansi. Bandung: ALFABETA.

Ghozali, Imam. 2013. Aplikasi Analisis Multivariate dengan Program IBM SPSS 21Update PLS Regresi. Semarang: Badan Penerbit Universitas Diponegoro.

Hery.2015. Analisis Laporan Keuangan. Edisi 1. Yogyakarta: Center For Academic Publishing Services.

Husein, Umar.2011.Metode Penelitian untuk Skripsi dan Tesis Bisnis, Edisi Kedua. Jakarta :PT. Raja Grafindo Persada

Juliansyah Noor, 2015. Metode Penelitian. Jakarta : Kencana.

Kasmir. 2016. Analisis Laporan Keuangan. Jakarta: Raja Grafindo Persada.

Kasmir. 2013. Analisis Laporan Keuangan.Jakarta: PT Raja Grafindo Persada.
Nurafika, Rika Ayu. " Pengaruh Perputaran Kas, Perputaran Piutang, Perputaran Persediaan terhadapProfitabilitas pada perusahaan semen", Jurnal Akutansi dan Bisnis, Volume 6, Nomor 1, Mei 2018.

https://scholar.google.co.id Diakses pada bulan juni 2020 .

Munawir, S. 2010. Analisis laporan Keuangan Edisi keempat. Cetakan Kelima Belas. Yogyakarta:Liberty

Sartono.2010. Manajemen Keuangan Teori dan Aplikasi. Edisi. Keempat. Yogyakarta: BPFE.

Syamsudin, Lukman, 2011, Manajemen Keuangan Perusahaan, Edisi Baru, Jakarta:PT. Raja Grafindo Persada.

Sodikin dan Riyono. 2014. Akuntansi Pengantar I. Yogyakarta: Sekolah Tinggi Ilmu Manajemen YKPN.

Sugiyono. 2012. Metode Kuantitatif, Kualitatif, dan $R \& D$. Bandung : Alfabeta.

Sugiyono. (2016). Metode Penelitian Kuantitatif Kualitataif dan Kombinasi (Mixed Methods).Bandung: Alfabeta.

Utami, Nurul Pratiwi.” Pengaruh Perputaran kas, Perputaran Piutang dan Perputaran Persediaan terhadap Profitabilitas Perusahaan Non Perbankan yang terdaftar pada LQ45Perode 2008 - 2012".

www.icmd.co.id. Diakses pada bulan April 2020.

www.idx.co.id. Diakses pada bulan April 2020.

www.sahamok.com. Diakses pada bulan April 2020 